\title{
Категория гоноратива в греко-католических молитвословиях ${ }^{1}$ The category of the honorific in Greek Catholic Prayers
}

\author{
Anna Petrikova \\ Inštitút rusistky, Uniwersytet Preszowski, \\ ul. 17. novembra 1, 08001, Prešov, Słowacja; \\ e-mail: anna.petrikova@unipo.sk
}

\begin{abstract}
Резюме
В статье анализируются греко-католические молитвы и использование категории гоноратива в них. По отношению к Господу Богу, Богородице, к Святым в обращении к ним используется гоноратив формы Ты - Вы. Это особая лексическая форма вежливости. Известное традиционное Вы, несущее значение уважения к адресату в религиозных текстах (проповедях, молитвах), заменяется гоноративной формой - Ты. В статье подчеркивается роль гоноратива в религиозной коммуникации, его функционирование в религиозном тексте, так как гоноративные (почтительные) формы применяются для характеристики действий уважаемых (с точки зрения говорящего) лиц. Материал исследования представляют тексты молитвословий, текстов славянских акафистов, которые используются в Восточном богослужении.
\end{abstract}

Ключевые слова: гоноратив; адресат, греко-католический; православный; словацкий; русский; славянский; акафист; перевод.

\begin{abstract}
The article analyzes the Greek Catholic prayers and use of the honorific category therein. To appeal to the Lord, Theotokos and the saints, the form You (sg.) is used. It is a special lexical form of politeness. The well-known traditional you (pl.) where respect for the addressee is expressed in religious texts (sermons, prayers) is replaced by the honorific form of You (sg.). The article emphasizes the role of the honorific in religious communication, its functioning in the religious text since honorific (respectful) forms are used to describe the actions of individuals commanding respect (from the speaker's point of view). The researched material consists of the texts of the prayers and Slavonic Akathists which are used in the Eastern Worship.
\end{abstract}

Keywords: honorific; addressee; Greek Catholic; Orthodox; Slovak; Russian; Slavic; Akathist; translation.

Греко-католические молитвословия как объект нашего исследования функционируют в религиозной коммуникации на территории Словакии, где

${ }^{1}$ Publikácia predstavuje výstup z grantovej úlohy VEGA Vplyv aktuálnych smerov lingvistického výskumu na jazykovednú terminológiu (v slovensko-pol'sko-ruskom komparatívnom pláne) č. 1/0180/17. 
пересекаются пространства Slavia orthodia a Slavia latina. Согласно теории Рикардо Пиккио данные термины не обозначают этническое или географическое понятие, а единое духовное пространство южных и восточных православных славян, принявших христианство и церковную культуру от Византии в IX-X вв., имеющих церковнославянскую письменность и богослужение. Итальянский славист считает, что «Западные славяне и часть южных, на землях которых в X-XI вв. византийские традиции были вытеснены влиянием Рима и латинской культурой, образуют единую духовную общность католического славянства - Slavia romana» (Пиккио 2003: 10). На территории Словакии, согласно утверждению П. Женюха (2016), действовала Папская булла Industriae tuae папы Иоанна VIII (880 г.), которая была адресована великоморавским князьям и не только позволяла использование славянской литургии, но и обязывала читать Евангелие при отправлении богослужения на славянском и латинском языках. Словацкая религиозная и культурная идентичность с древнейших времен развивается под влиянием Кирилло-мефодиевской традиции. Особенно это отразилось на населении Восточной Словакии, где на протяжении веков сосуществуют словацкий и русинский этносы.

Молитва как жанр религиозного текста была и остается объектом интереса специалистов разных областей - богословов, религиоведов, лингвистов, литературоведов, фольклористов. Существуют различные критерии классификации молитвы и методы ее исследования. Изучаемый нами коммуникат в Спиритуальном словаре определяется посредством концепта Вера, как «а) вера в единосущного, живого Бога; б) вера в его реальное присутствие; в) вера в настоящий диалог между человеком и Богом» (de Fiores, Goffi 1999: 524). В лингвистике молитва понимается как речевой акт, совершающийся «между человеком и субъектом из сакральной сферы» (Makuchowska 1998: 47), а также как «тип текста, который является наиболее значимым в содержательном отношении и отражает наиболее характерные языковые параметры стиля» (Прохватилова 2007: 154). Таким образом, молитва - это форма особого диалога с конкретными прагматическими функциями. Основной функцией молитвы является фатическая функция, т.е. установление глубокой, живой связи (контакта) с Господом Вседержителем, с Матерью Божей, со святыми. Данное языковое явление импрессивно и реализуется в форме просьбы. Установление связи начинается с аппелящии экспедиента к Богу, Богородице, святым. Вовлечение в речевой акт молитвы происходит в различных лествичных ступенях молитвы в зависимости от того, какой из ее элементов обнаруживается в наибольшей степени. Феофан Затворник представляет следующий традиционный перечень этих ступеней: 1) телесная, или молитвословная молитва; 2) умная молитва; 3 ) умносердечная, сердечная молитва, или чувства; 4) духовная, или созерцательная молитва» (Шпидлик 2000: 362). К третьему виду молитв можно отнести сердечную молитву греко-католического обряда - Иисусову молитву (ustavičná modlitba (1 Sol 
5,17), modlitba srdca) Pane Ježišu Kriste, Synu Boží, zmiluj sa nado mnou hriešnym (церковнослов.: Господи Иисусе Христе, Сыне Божий, помилуй мя грешнаго). Таким образом, основными способами воплощения считаются внешние (гласные и устные) и внутренние (мысленные) молитвы. Существуют и более детализированные типы внешних молитвословий по адресату, содержанию, времени, структуре, объему и т.д. (см.Прохватилова 1999) По структуре молитвословия состоят из нескольких речевых шагов: восхваление (славословие) Бога, благодарение, просьба (призыв) за прощение грехов, просьба (-ы), обращенная к Богу и заключительная реплика «Аминь». Экспедиентом текста является молящийся субъект, homo orans, почтительно относящийся к адресату (Господу, Богородице, святым), слушающий его и отвечающий ему. Кроме того, участниками коммуникации при обращении в религиозном дискурсе могут быть и несколько субъектов: homo orans homo orans.

По мнению И.В. Бугаевой «адресация в молитве - многоступенчатая:

- Суперагенс 1 порядка - Бог (Святая Троица, Сын Божий как одна из Ее ипостасей);

- Суперагенс 2 порядка - Силы Небесные;

- агенс 3 порядка - святые;

- агенс 4 порядка - священники (отче, помолитесь обо мне);

- агенс 5 порядка - миряне (молитва друг за друга, просьбы сугубых молитв о болящих, путешествующих и т.д.)» (Бугаева 2013: 16).

Почтительное отношение к адресату выражается посредством языковой категории, гоноратива, связанного с выражением уважительного отношения одного лица к другому лицу или другим лицам. В словацком языкознании гоноратив исследует Й. Мистрик, который определяет термин как «способ выражения социальных отношений между говорящим и адресатом в процессе речевой коммуникации» (Mistrík 1981: 256). Степень почтительного отношения в словацком языке выражается личными и притяжательными местоимениями ja - môj, ty - tvoj, on, ona, ono-jeho, jej, jeho/tvoj, svoja, svoje, $m y-n a ́ s ̌, ~ v y$ - váś, oni/ony - ich, видоизмененными формами глаголов, а также обращениями. Обращение характеризуется как слово или группа слов, которые называют того, к кому адресована речь. В российской лингвистивке гоноратив исследует В.И. Карасик, который считает, что посредством гоноратива выражается категория социального статуса, внутренняя формула которой «имеет три глубины измерения (коммуникативная, социальная и репрезентативная). Если репрезентативное измерение статуса формально представлено в языке, значит, в этом языке категория социального статуса находит многообразные способы выражения в грамматике и лексике и относится к числу характерологических категорий для данного языка. Если же репрезентативное измерение статуса формально не представлено, то категория статуса выражается лексически, стилистически и имплицитно-грамматически» (Карасик 2002: 200). Гоноратив используется для статусной 
репрезентации, выражающей отношение с восходящим вектором по линии возвышения адресата и самоуничижения говорящего. Статусная репрезентация в религиозной коммуникации основана на нормах христианской нравственности и отличается от этикета секулярного общества.

В российской лингвистике выделяют три группы форм гоноратива: собственно гоноративные (почтительные), депрециативные (скромные) и нейтральные. Стандартно-нейтральный гоноратив может выражаться в языках: 1) с помощью дейксиса, то есть местоименной или полуместоименной номинации, связанной с категорией лица и числа (Шафиков 2011a); 2) с помощью адрессива, то есть субстантивной номинации, которая может ставиться перед именем лица или употребляется отдельно (Шафиков 2011b).

В религиозной коммуникации посредством гоноратива выражается отношение молящегося к адресату (Mistrík 1981). Одна из самых распространенных форм гоноратива - это использование «ты»-сферы высказывания.

Рассмотрим функционирование «ты»-высказываний в молитвах, звучащих во время литургии св. Иоанна Златоуста: заамвонная молитва: Pane, ty žehnáš tým, čo ti dobrorečia, a posväcuješ tých, čo dúfajú v teba. Spas svoj l'ud a žehnaj svoje dedičstvo, ochraňuj plnost’ tvojej cirkvi, posväcuj tých, čo milujú krásu tvojho domu. Osláv ich svojou božskou mocou a neopúšt'aj nás, v teba dúfajúcich. Daruj pokoj svetu, svojim cirkvám, kňazom, našim svetským predstaveným i všetkému svojmu l’udu; изобразительные псалмы (Пс. 102-й): Dobroreč, duša moja, Pánovi a celé moje vnútro jeho menu svätému. Požehnaný si, Pane. Ako je vzdialený východ od západu, tak vzd'al'uje od nás našu neprávost'. Požehnaný si, Pane. Dobrorečte Pánovi, všetky jeho diela, všade, kde on panuje. Dobroreč, duša moja, Pánovi.

Как показывают примеры, гоноратив выражается с помощью местоименных форм ty, ti, t'a, teba, tebe, tvoje, si, svoje, jeho. Грамматическая категория лица, а также глагольные формы выражают высокую степень почтительного отношения коммуниканта к адресату.

Далее приведем примеры адрессивов из литургии св. Иоанна Златоуста на словацком и церковнославянском языках (транскрипция на латинице):

A dovol' nám, Vládca, $s$ dôverou a bez strachu $z$ odsúdenia vzývat' teba, nebeského Boha Otca a povedat' (spodóbi nás, Vladyko, s derznovénijem neosuždénno smiti prizyváti Tebé nebésnaho Bóha Otcá, i hlahólati); Lebo ty si svätý, Bože náš, a my ti vzdávame slávu, Otcu i Synu i Svätému Duchu, teraz i vždycky (Jako svját jesí, Bóže náš, i tebí slávu vozsylájem, Otcú, i Synu, i svjatómu Dúchu, nýňi, i prison); Sláva tebe, Pane, sláva tebe (Sláva Tebí, Hóspodi, sláva Tebí); Pane a Vládca, Bože našich otcov, prosíme t’a, vypočuj nás a zmiluj sa (Hóspodi vsederžítel'u, Bóže otéc nášich,mólim ti sja, uslyši i pomiluj); Ospevujeme t'a, zvelebujeme t'a, d'akujeme ti, Pane, a prosíme t'a, Bože náš (Tebé pojém, Tebé blahoslovím, Tebí blahodarím, Hóspodi, i mólimtisja, Bóže náš); Dôstojné je velebit’ teba, Bohorodička, vždy blažená a nepoškvrnená i Matka 
nášho Boha (Dostójno jést' jáko voístinnu blažiti Ťá Bohoródicu, prisnoblažénnuju i preneporóčnuju, i Máter Bóha nášeho).

Как показывают примеры, кроме гоноративов, выраженных местоименными формами ty si, ti, t’a, teba, tebe, jeho, почтительное отношение выражается с помощью адрессивов, т.е. форм субстантивных номинаций, а также глагольных форм высокого книжного стиля (vzývat', vzdávame, ospevujeme, zvelebujeme, velebit' и т.д.).

Субстантивум Pane, Bóže, Synu Boží, окончивающиеся на $e$, -i используются в форме звательного падежа (так наз. vokativ):

Pane, zmiluj sa (Hóspodi, pomíluj); Zastan̆ sa a spas nás, zmiluj sa a zachrán̆ nás, Bože, svojou milostou (Zastupí, spasí, pomiluj i sochraní nás, Bóže, tvojéju blahodátiju.); Pred tebou, Pane (Tebi, Hóspodi); Daruj nám, Pane (Podáj, Hóspodi); Spas nás, Synu Božrí, obdivuhodný vo svojich svätých (Spasí ny, Sýne bóžij, vo svjatých diven sýj); Pane, spomeň si na mňa, ked' prídeš do svojho královstva (Vo cársviji tvojém, (jehdá priídeši,) pomjani nás Hóspodi).

Согласование субстантивной номинации с глаголом проводится по грамматическим показателям лица, единственного числа, повелительного наклонения, обозначающего просьбу, призыв (императив): dovol', zmiluj sa, spas,

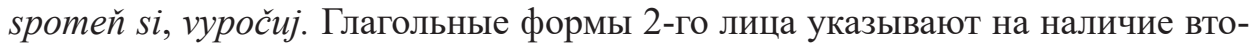
рого участника религиозной коммуникации.

Считается, что использование звательного падежа в религиозной коммуникации связано с соблюдением ритма и звукового сходства. Рассмотрим примеры:

Молитвы: Král'u nebeský, Utešitel'u, Duchu pravdy...; Otče náš, ktorý si na nebesiach, - posvät'sa meno tvoje...;

Песнопение: Príd' už, príd' už, Spasitel'u, - udel' duši, nášmu telu; Duchu Svätý zostup k nám, - posvät' našich duši chrám; Králu nebeský, Boh všemohúci, Duch Utešitel', Duch pravdy sám; Požehnaj všetkých, Ježišu milý, - čo tvojmu Srdcu vzdávajú čest'.

Структурно-семантические формы вокатива представлены ввиде наименований, состоящих из перифрастических определений и символических метафор по отношению к Господу, например, Ježišu, Baránok nepoškvrnený; Ježišu, Pastier obdivuhodný; Ježišu, prameň múdrosti, а также к Богородице: úrodná vinica; zornica, hlbina.

Анализ обращений в большинстве молитвословий показал, что эти обращения представляют собой наименования Господа, Богородицы, святых, мучеников и мучениц, архангелов и ангелов, апостолов. Приведем примеры:

Обращение к Господу Богу: Bože, Bože náš, Svätý Bože, Pane, Ježušu, Kriste, Kriste Bože, Bože, Synu Boží, Synu Boha živého, Králu nebeský, Dobrotivý, Vládca, Stvoritel', mocnývojvodca, premožitel'pekla, Duchu, Spasitel'u, Vykupitel'u, Pane mocný, Tvorca anjelov a Pane mocností; Ježišu presladký, Ježišu preslávny, Ježišu prelubezný, Ježišsu prepodivný, Ježišu najtichší, Ježišu najláskavejší, Ježišsu najmilosrdnejší, Ježišu presladký, Ježišu predvečný. 
Обращение к Богородице: Bohorodička, mocná Vládkyňa; najsvätejšia Panna; panenská Nevesta; navädnúca ratolest’ stromu života; Matka Baránka a Pastiera; Vojvodkyn̆a veriacich; veniec striedmosti; košatý strom; prečistá Pani.

Обращение к святым, страстотерпцам, апостолам: Jozef, ochranca svätej Cirkvi; preslávny ženich; svätý Jozef; starostlivý ochranca Svätej rodiny; hieromučeník Jozafát; Kristov hieromučeník; svätý Jozafát; popredný mnich; svätí Cyril a Metod; prvoučitelia Slovanov; otcovia našej cirkvi; slovanski, apoštoli; spolupatróni Európy; preslávni učitelia; blažený Pavol; blažený otec a mučeník Pavol; blažený biskup a mučeník Pavol; blažený Metod; ozdoba reholného života; vel'kňaz a patriarcha Atanáz; svätý apoštol Jakub; svätý apoštol Šimon; znamenitý prorok Eliáš; ctihodná Mária Magdaléna; Bohom omilostená Anna; mučeník Kristov, Metod.

Кроме молитвословий атрибут при обращениях чаще всего используется в акафистах ${ }^{2}$, состоящих из хвалебных песнопений, а также в канонах, посвященных прославлению праздника или како-нибудь святого. Данные (канонические) коммуникаты являются жестко формализированными текстами. В них проявляются признаки ритуала (ролевая структура, статусные отношения, высокая символичиность).

Одним из древних акафистов считается Великий акафист Пресвятой Богородище (Взбранной воеводе), который был написан к освобождению Константинополя от нашествия персов приблизительно в 626 году «на основе еще более древних кондаков, в которых воспеваются события Рождества Господа и Благовещения Пречистой Богородицы» (Настольная книга священнослужителя I. 1977: 543). Новые акафисты возникают по образцу первого акафиста.

Существует несколько версий авторства гимна. Православная традиция акафистное пение относит к византийскому гимнографу VI столетия Роману Песнописцу. Некоторые считают, что автором мог быть патриарх Константинопольский Герман. Другие исследователи приписывают авторство монаху Косме Песнописцу. Чешский богослов Иржи Новотный утверждает, что автор неизвестен (Novotný 1995: 30), но к самому началу IX в. существовал полный латинский перевод Акафиста, возникший в среде швейцарских монастырей.

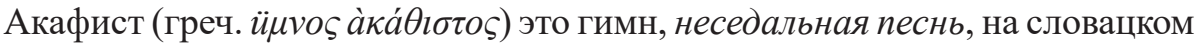
языке akatist (nesedalen) - особые хвалебные песнопения в честь Спасителя, Божьей Матери или святых. Во время пения акафиста принято стоять. Согласно «Полному церковнославянскому словарю» под редакцией священника Г. Дьяченко (1993), данное молитвословие состоит из 25 песен $^{3}$, которые

\footnotetext{
2 Акафист является одним из основных гимнографических жанров греческого языка.

${ }^{3}$ Если не считать первый кондак, то получится 24 песен, столько же букв в греческом алфавите.
} 
расположены по порядку греческого алфавита ${ }^{4}: 13$ кондаков и 12 икосов ${ }^{5}$ (Полный церковнославянский словарь 1993: 11).

Важнейшая составная часть каждого икоса и характерная примета структуры акафиста в целом - так называемые хайретизмы, т.е. обращения к воспеваемому предмету, начинающиеся греческим приветствием «хайре» ${ }^{6}$ $\left.(\chi \alpha i \rho \varepsilon),(« р а д у и ̆ с я)^{7}\right)$ и развертывающиеся в многословное именование этого предмета (например, «радуйся, о премудрости божией вместилище!»). Первый кондак и все последующие икосы заканчиваются восклицанием Raduj sa, panenská Nevesta! (рádyŭcя, Неве́сто неневе́стная) ${ }^{8}$. Остальные кондаки заканчиваются кондачным рефреном, восклицанием - «Аллилуйя» (на еврейском - «хвалите Бога»), которое адресовано только Господу Богу. Восклицание panenská Nevesta (Невеста Неневестная), представляет эпитет ${ }^{9}$, включающий дескриптор panenská, который мотивирован духовными качествами и целомудренностью Богородицы. Субстантивум Nevesta указывает на взятый на себя подвиг, быть Матерью Бога-Слова. Этот номинатор содержит важную ценность особенно для христианской цивилизации как с догматической точки зрения, так и историко-культурной. Эпитет panenská Nevesta (Невеста Неневестная) указывает на внутреннюю, церковную сущность предмета, называет признак, составляющий его духовный смысл. Роль эпитета сводится к духовному воздействию, к участию в формировании у молящегося мировоззренческих ценностей, ориентиров.

${ }^{4}$ Согласно подлиннику греческий алфавитный акростих составлен так, что чередующиеся кондаки и икосы начинаются каждый раз с новой буквы греческого алфавита в их строгой очередности - от альфы («Ангел предстатель...») до омеги («О всепетая Мати...» - по-славянски это видно как раз только на примере первого икоса и последнего, тринадцатого кондака) (Акафист Пресвятой Богородице с комментариями b.r.).

5 Содержание акафиста: а) историческая часть: библейские события от Благовещения по (А-М; Икос 1 - Кондак 7) до Сретения Господня в храме, Симеон Богоприимец; б) богословско-догматическая часть: (N- $\Omega$; Икос 7 - Кондак 13).

${ }^{6}$ Или «хере».

7 Источник «Радуйся» в Священном Писании - «Радуйся, Благодатная! Господь с Тобою» ( Евангелие от Луки $(1,28)$ ).

8 Дева Мария - Невеста, у Которой нет жениха, или мужа, в плотском смысле (именно такое значение имеет слово «неневестная»), но Которая безмужно, бессеменно стала Матерью Господа нашего Иисуса Христа (Акафист Пресвятой Богородице с комментариями b.r.)

9 Эпитет - стилистический приём, образное определение, не только указывающее на признак определяемого явления, но и сообщающее этому признаку дополнительное значение переносное или символическое (Литературная энциклопедия, онлайн). Эпитет как языковая форма выражения выступает как средство раскрытия смысла, поскольку связан с содержанием, формирует и воплощает его (Лотман 1998). 
Структура хайретизма состоит из многокомпонентного обращения. Рассмотрим языковую модель церковнославянского акафиста в русской транслитерации ${ }^{10}$ и словацкого акафиста, который молятся греко-католики ${ }^{11}$ :

1. Обращение, выраженное субстантивом с зависимыми словами:

1 Икос

Радуйся, падшаго Адама воззвание; радуйся, слез Евиных избавление.
1 Ikos

Raduj sa, lebo si pozdvihla padnutého Adama! Raduj sa, lebo si zotrela slzy Evine!

Греко-католический акафист: обращение, выражено не субстантивом с зависимыми словами, а придаточным предложением причины с союзом lebo (ибо, потому что, так как).

2. Причастный оборот в функции развернутого обращения:

\section{2 Икос}

Радуйся, Свет неизреченно родившая; радуйся, еже како, ни единаго же научившая

\section{3 Икос}

Радуйся, Делателя делающая

Человеколюбца;

радуйся, Садителя жизни нашея рождшая

\section{Ikos}

Raduj sa, lebo si porodila svetlo zázračné! Raduj sa, lebo si zachovala v srdci tajomstvo!

3 Ikos

Raduj sa, ty, ktorá si urobila Stvoritel’a milovníkom l'udí!

Raduj sa, lebo si porodila rozsievača života!

Греко-католический акафист: обращение, выражено не причастным оборотом в функции развернутого обращения, а причинным придаточным предложением с союзом lebo (ибо, потому что, так как), придаточным предложением с местоименным союзным словом ktorá (которая).

\section{3. Придаточное относительное, зависящее от подвергшемуся эллипсису местоимения «Еюже» ${ }^{12}$ :}

\section{1 Икос}

Радуйся, Еюже радость возсияет; радуйся, Еюже клятва изчезнет

\section{Ikos}

Raduj sa, lebo skrze teba k nám radost' prichádza! Raduj sa, lebo skrze teba pominie prekliatie!

\footnotetext{
10 Акафист Пресвятой Богородице с комментариями b.r.

11 Akatist k presvätej Bohorodičke b.r.

12 «Еюже»- церковнославянское относительное местоимение «которой» (творит, пад.).
} 
Греко-католический акафист: обращение, выражено не придаточным относительным местоимением «Еюже», а причинным придаточным предложением с союзом lebo (ибо, потому что, так как).

4. Обращение, выраженное придаточным предложением с союзами яко, бо:

9 Икос

Радуйся, яко обуяша лютии взыскателе; радуйся, яко увядоша баснотворцы

\section{0 Икос}

Радуйся, Ты бо обнови́ла еси зачатыя студно;

радуйся, Ты бо наказала еси окраденныя умом
9 Ikos

Raduj sa, ved' pred tebou sú nevedomí aj mudrci!

Raduj sa, lebo pred tebou zhasla sláva básnikov!

\section{Ikos}

Raduj sa, lebo obnovuješ v hriechu počatých! Raduj sa, učitel'ka sklamaných!

Греко-католический акафист: в Икосе 9 обращение выражено не придаточным предложением с союзами яко, бо, а причинным союзом ведь со значением обоснования, причинным придаточным предложением с союзом lebo (потому что). В Икосе 10 первый хайретизм включает союз бо, присоединяющий придаточное предложение причины. В данном случае подчеркиваем одинаковую синтаксическую конструкцию, но расходящиеся по времени (бо обнови́ла - прошедшее время; lebo obnovuješ - настоящее время). Второй хайретизм не содержит придаточную конструкцию, а субстанивум učitel'ka + причастие sklamaných.

В акафисте встречаются и другие структуры уважительного обращения к Богородице, включающие разнообразные атрибуты, многие из которых связаны с конкретными повествовательными сценами и упоминаются в связи с ними. Многие из символов заимствованы из Священного Писания, из Песни Песней Соломона. Наиболее обычны следующие атрибуты в составе хайретизмов:

Натуроморфизмы - это выражения, описывающие предмет через приписывания Ему качеств, присущих природным явлениям: огню (Втор. 4, 24), свету (Ин. 1, 9) (Добыкин, 2012: 89).

11 Икос

Радуйся, луче умнаго Солнца; радуйся, светило незаходимаго Света. Радуйся, молние, души просвещающая;

\section{Ikos}

Raduj sa, lúč duchovného slnka! Raduj sa, žiara neuhasínajúceho svetla! Raduj sa, blesk, čo ožaruje duše! Raduj sa, búrka, čo desí nepriatel'a! 
Антропоморфизмы - это выражения, описывающие предмет через приписывания Ему членов человеческого тела: сердца (Ос. 11, 8), глаз (Пс. 10, 4), ног (Быт. 3, 8), уст (Чис. 12, 8), мышц (Исх. 15, 16), пальцев (Втор. 9, 10):

\section{1 Икос}

Радуйся, утробо Божественнаго воплощения.

\section{Ikos}

Raduj sa, lono, v ktorom sám Boh prebýval!

Фитоморфизм отражает процесс наделения всего сущего посредством метафоризации свойствами предметов и явлений растительного мира.

\section{7 Икос}

Радуйся, цвете нетления;

Радуйся, древо светлоплодовитое, от негоже питаются вернии;

радуйся, древо благосеннолиственное, имже покрываются мнози

\section{Ikos}

Raduj sa, kvet, ktorý nikdy nevädne!

Raduj sa, sladké ovocie stromu, ktoré živí veriacich!

Raduj sa, košatý strom, v ktorého tieni mnohí oddych nachodia!

Локоморфизм как языковое явление отражает соизмеримость сущего с пространственными параметрами и объектами. Семантика образных слов и выражений метафорически воплощает локоморфные образы.

\section{2 Икос}

Радуйся, селение Бога и Слова

Радуйся, Церкве непоколебимый столпе; радуйся, Царствия нерушимая стено

\section{2 Икос}

Радуйся, лествице небесная, Еюже сниде Бог; радуйся, мосте, преводяй сущих от земли на небо

\section{Ikos}

Raduj sa, Bohu i Slovu vhodný príbytok!

Raduj sa, Božej cirkvi pevná opora!

Raduj sa, bezpečná hradba král'ovstva!

\section{Ikos}

Raduj sa, rebrík, po ktorom sám Boh z neba zostúpil!

Raduj sa, most, po ktorom l'udstvo zo zeme do neba prechádza!

В церковнославянском языке имеется звательный падеж со своим окончанием, утраченным в современном русском языке. Поскольку все без исключения хайретизмы - это обращения к Богородице, Ее именования стоят в звательном падеже: существительные женского рода: окончание «а» меняется на «о» или «е»: невеста/ невесто; высота/ высоте; глубина/ глубинно; 
звезда/ звездо; розга/ розго; лествииа/ лествиие и т.д. Имена мужского рода получают окончание «е»: мост/ мосте; двор/ дворе. На существительных среднего рода («воззвание», «избавление», «древо») это не отражается.

Таким образом, применительно к категориальной форме статуса следует подчеркнуть, что гоноратив проявляется в функционально-грамматической и функционально-стилистической религиозных сферах языка. Постредством гоноратива и адрессива молящийся субъект передает уважительное отношение к адресату. Что касается использования императивных форм глаголов, то они тесно связаны с выражением доверительного отношения между молящимся и адресатом, причем говорящий просит его выполнить какую-то просьбу в интенции «Proste a dostanete. Hladajte a nájdete! Klopte a otvoria vám!» (Mt 7, 7). Анализ языковых моделей церковнославянского акафиста в русской транслитерации и словацкого акафиста показал на многие отклонения, возникшие при переводе текстов. Первое из них - это частичная передача псевдоалфавитного акростиха, т.е. совокупности начальных слов в строфах Великого акафиста, поскольку невозможно точно перенести на европейские (славянские) языки греческий акростих. В качестве лексем основного типа славянского псевдотекстового акростиха гимна можно привести следующие словоформы, встречающиеся в начале строф: церковнос. взбранной/ словацк. тосná vládkyn̆a, spievame vit’aznú piesě̆; церковнос. ангел/ словац. archanjel; церковнос. видящи/ словац. istá si svojím panenstvom; церковнос. разум/ словац. túžobne želala pochopit; церковнос. сила/ словац. Mос Najvyššieho; церковнос.имуши/ словац: v živote Boha nosila; церковнос. бурю,/ словац. Jozef umáral sa pochybnostami; церковнос. сльишама/ словац. počuli spev anjelov; церковнос. боготечную/ словац. jasnú hviezdu; церковнос. видеша/ словац. synovia uvideli; проповедницьl/ словац. traja mudrci; церковнос. возсиявый/ словац. ty si svetlom svojej pravdy ožiaril; церковнос. хотящу/ словац. zatúžil po večnom živote; церковнос. новую/ словац. nové stvorenie nám ukázal; церковнос. странное/ словац. Na nеobyčajné stvorenie; церковнос. весь/ словац. ty celé v nebi aj na zemi prebývaš; церковнос. Всякое/ словаu. V̌̌ etky anjelské zbory; церковнос. ветия/ словац. slávni rečnici zmíkli; церковнос. спасти/ словац. aby spasil svet; церковнос. стена/ словац. ty si vzorom panien a všetkých; церковнос. пение/ словац ani najkrajšia piesen̆ nетоิže; церковнос. светоприемную/ словац. ako svetelná pochodeñ; церковнос. благодать/ словац. Pán milosrdenstva sa rozhodol odpustit; церковнос. поюще/ словац. Velebíme tvojho Syna. Наблюдение показало, что псевдооригинальный акростих присутствует частично только в гимнографическом тексте на церковнославянском языке ${ }^{13}$. Однако по славяно-русской

13 В греческом оригинале акафист начинается с альфы - первой буквы греческого алфавиты. Последующие строфы начинаются с беты, гаммы, дельты и так далее - вплоть до омеги (междометия о) в 13-м кондаке. Таким образом, Великий акафист (как и все написанные позже греческие акафисты), содержит алфавитный акростих: первые буквы 24 строф (кондак 
акафистной традиции закрепились слова, которые оказались на первом месте в той или иной строфе в результате перевода Великого акафиста. Поэтому почти во всех славянских акафистах 1-й икос начинается со слова Ангел (или его производных), 2-й кондак - с форм глагола видети, в начале 4-го кондака буря и т.д. На словацком языке используется фразовый акростих ${ }^{14}$ с элементами псевдооригинального акростиха в Кондаках 3, 9 и 12. Переводчик приспособил текст к словацким условиям, пожертвовав при этом точностью следования оригиналу.

Как показал анализ, языковая модель благоговейного почитания Богородицы (обращения к ней) в коммуникате акафиста многокомпонента. Структура хайретизма состоит как из моделей простых, так и сложных конструкций. Хайретизмы организованы как перифрастические определения и символические метафоры.

Акафист можно интерпретировать как аллегорию отношений между Иисусом Христом и Его Матерью. Его функция состоит в духовном воздействии на молящегося, на формирование у коммуниканта христианских мировоззренческих ценностей, вополощения живого учения Иисуса Христа в жизни.

\section{БИБЛИОГРАФИЯ}

Аверинцев С.С., 1976, Традиция греческой «диалектики» и возникновение рифмы, Москва, с. 81-99.

Акафист Пресвятой Богородице с комментариями, https://azbyka.ru/molitvoslov/akafist-presvyatoj-bogorodice-s-kommentariyami.html\#i2 [dostęp: 21.05.2017].

Библия. Книги священного Писания Ветхого и Нового Завета, 1997, Москва.

Бугаева И.В., 2013, Особенности номинации адресата в религиозной сфере, в: Теолингвистичка проучавања словенских језика, Београд, с. 15-26.

Добыкин Д.Г., 2012, Лекции по введению в Священное Писание Ветхого Завета, Санкт-Петербург.

Женюх П., 2016, Кириллическая рукописная традиция и культурная идентичность византийско-славянской традиции под Карпатами (на примере восточной Словакии), w: История, язык, культура Центральной и Юго-Восточной Европь в национальном и региональном контексте. К 60-летию К.В. Никифорова, отв. редактор, Е.С. Узенёва, Москва, с. 558-576.

Карасик В.И., 1992, Язык социального статуса, Москва, http://philologos.narod.ru/ texts/karasik/status16.htm [dostęp: 23.01.2017].

Лотман Ю.М., 1998, Риторика, в: Об искусстве, Санкт-Петербург.

Пиккио Р., 2003, Slavia orthodia, в: Литература и язык, Москва.

«Взбранной Воеводе...» не входит в это число) образуют полный классический греческий алфавит (Людоговский www).

${ }^{14}$ Фразовый акростих составляется не из начальных букв, а из начальных слов или слогов. 
Литературная эничиклопедия В.М. Фриче, 1929-1939, СИЭ-А-А.П. Горкина, СЛТ-М. Петровский, http://alcala.ru/literaturnaia-enciklopedia/slovar-EA/6804.shtm [dostęp: 20.03.2017].

Людоговский Ф.Б., 2015, Структура и поэтика иерковнославянских акафистов. Москва.

Людоговский Ф.Б., 2013, Акафист Богородице был написан как алфавитный акростих, в: Жизнь в Церкви, http://www.nsad.ru/articles/akafist-bogorodice-byl -napisan-kak-alfavitnyj-akrostih [dostęp: 20.03.2017].

Настольная книга священнослужителя, 1977, Том I, Москва.

Полный иерковнославянский словарь. Составил священник магистр Г. Дьяченко (с внесеніемъ въ него важнъйшихъ древне-русскихъ словъ и выраженійю), 1993, Москва.

Попов А.В., 2013, Православные русские акафисты, Москва.

Прохватилова О.А., 2007, Православная молитва как один из ядерных жанров религиозного стиля, в: Стил, с. 153-166, http://www.rastko.rs/cms/files/books/49e5944e7b5c9 [dostęp: 20.04.2017].

Фундули И., Акафистное пение Богоматери, https://apologet.spb.ru/en/component/ tags/tag/54.html [dostęp: 18.03.2017].

Шафиков S.G., 2011a, Европейская веживость в свете метоимений, w: Человеческий фактор в языке и культуре, Уфа, с. 88-94

Шафиков S.G., 2011b, Господин, госпожа и дама, илил гоноратив в межъязыковом освещении, в: В многомерном пространтсве языка (к юбилею проф. Л.М. Васильева), Уфа, с. 113-116.

Шпидлик Ф., 2000, Духовная традиция Восточного христианства. Систематическое изложение, Москва.

Akatist k presvätej Bohorodičke, http://kniznica.casoslov.sk/akatist-k-presvatej-bohorodicke [dostęp: 17.04.2017].

Makuchowska M., 1998, Modlitwa jako gatunek języka religijnego, Opole.

Mistrík J., 1981, Honoratív v slovenčine, „Studia Academica Slovaca”, nr 10, Bratislava, s. $255-268$.

Novotný J., 1995, Komentaře. Mariánský hymnus. Akathistos, Velehrad.

Petrikova A., Kopcakova S., 2018, Analysis of word and music interconnection in Greek Catholics 'liturgical chanting on interdisciplinary aspect of linguistics and aesthetics, „Xlinguae”, Volume 11, Issue 2, April, s. 768-783.

Fiores de S., Goffi T., 1999, Slovník spirituality, Kostelní Vydří. 